\title{
An IT governance framework for achieving the development of Academic Programme in Higher Institutions: A case of Universiti Malaysia Sarawak (UNIMAS)
}

\author{
Nadianatra Musa ${ }^{1}$, Dayang Hanani Abang Ibrahim² ${ }^{2}$, Noor Alamshah Bolhassan ${ }^{3}$, Johari Abdullah ${ }^{4}$, Narayanan \\ Kulathuramaiyer ${ }^{5}$, Mohamad Nazri Khairuddin ${ }^{6}$ \\ Faculty of Computer Science and Information Technology \\ Universiti Malaysia Sarawak (UNIMAS) \\ Kota Samarahan, Sarawak, Malaysia \\ \{nadia, hananii, bnalamshah, ajohari, nara, kmnazri\}@fit.unimas.my
}

\begin{abstract}
In Information Technology (IT) Governance, the use of web has become a competitive strategy for aligning business goals and IT within an organization. IT Governance is a subset of corporate governance. IT Governance is the strategic alignment of IT with business so that maximum business value is achieved through the development and maintenance of effective IT control and accountability, performance management and risk management. As the Internet has connected the organization with people all over the world, providing an effective IT control and achieving risk management over the critical data and services. This is a challenging task to all sectors including education. We modeled a conceptual framework by identifying the elements of governance for achieving the development of academic programme through web based system. For the governance elements, data was collected using qualitative methods. This paper reports on the impact gained from the IT governance framework for the development of academic programme in UNIMAS.
\end{abstract}

Keywords- IT governance; IT governance framework; Academic Programme; Course Outline;

\section{INTRODUCTION}

For higher institutions which are publicly owned, good governance is very important. It acts as a bridge to connect between public sector strategy and higher institutions strategic actions. All public sector assets including IT infrastructures and business information are the responsibility of and accountability to the board of directors and senior managers. IT Governance provides a structure of relationships and processes to direct and control the enterprise in order to achieve its goals by adding value while balancing risk versus return over IT and its processes [1]. There are some existing IT governance frameworks that are widely used by industries and organizations including ISO38500 [2], COBIT [3], IT Control and Compliance [4], Standards for IS Audit [5], ISO 27001 [6], ITIL [7] and SAS70[8]. The Committee of Sponsoring Organisations of the Treadway Commission (COSO) is an example of governance frameworks for internal control[9]. However, each framework does have its own focus and motive.

[10] have divided IT governance into three distinct elements, IT Decision Domains, IT Governance Archetypes and Implementation Mechanism. The IT Decision Domains, provides a governance structure for a corporation such as IT principles, IT architecture, IT infrastructure, business application needs and prioritization and investments.

IT governance brings value and benefits to the organisation generated by IT investments [10]. The effect of IT value is significantly more important in industrial context. For example, high technology businesses rely primarily on the dissemination of information for innovation success and protection of information to retain a competitive advantage. The manufacturing business however concentrates on coordinating activities with their supply chain partners and conversely, retailing/services businesses are particularly market oriented. The availability of information is a vital to remain competitive in the market. For banking and financial businesses, their focus is on data integrity and confidentiality of customer information. However, in education, [11] has pointed out the education industry is now changing its landscape from centralized to more federated and decentralized where critical data and services are available electronically such as e-learning repositories, open source learning applications, Customer Relationship Management for enrolment management, web services for admin applications and library management materials.

Effective IT governance offers the use of the web as a competitive strategy to align with business goals [12]. The greatest technology tool in the universe namely the Online mode has improved the gap barrier in terms of the communication between administrators and their subordinates within a short period of time. In particular for Academic Institutions, the existing system known as Online Syllabus Generator [13] used by the Center for Learning Technologies, Old Dominion University, Norfolk found that the online tool has helped the faculty in syllabus preparation time, increase flexibility and efficiency in syllabus creation and able to communicate course goals and expectations. Acting as a record keeping tool, it also helps the faculty in curriculum planning and faculty evaluation purposes. The Online Syllabus Generator enables the faculty to easily create, adapt, manage and share course syllabi effectively and efficiently.

In Malaysia, universities are required to adhere to the Malaysian Qualification Framework (MQF), which was developed by the Malaysian Qualifications Agency (MQA) with regard to the course generation and course outline management. MQA had developed a set of criteria, which clarifies the academic levels, learning outcomes, and credit system based on student academic load. The Ministry of Higher Education (MoHE) had set the target 